\title{
Mentoring New Teachers and Introducing Them to Administrative Skills
}

\author{
Amos Oyetunde Alabi \\ Emmanuel Alayande College of Education, P.M.B 1010, Erelu, Oyo, Nigeria \\ E-mail: amosalabi@yahoo.com
}

Received: June 12, 2017 Accepted: July 10, 2017 Online published: August 7, 2017

doi:10.5296/jpag.v7i3.11362 URL: https://doi.org/10.5296/jpag.v7i3.11362

\begin{abstract}
This paper examined benefits of mentoring to the teachers especially the new teachers in the school system. The concept of mentoring was discussed vis-a-vis other related terms. The qualities of a mentor teacher were elucidated. How to start a mentoring programme as well as the four phases of mentoring relationship were fully highlighted and discussed. The "new teachers" to be introduced to administrative skills as identified by the paper are: those not trained in the teaching profession, those trained but entering into full time teaching for the first time, those trained teachers but not experienced in teaching $(1-4$ years $)$ and those already teaching but found teaching uninteresting. The skills on which the new teachers can be mentored includes: school records keeping, class(room) management, teaching effectiveness and efficiency, school community relations, school plant management and evaluation and assessment of students. Benefits of mentoring to old and new teachers were highlighted. Mentoring is one of the best reforms in the education system and a very cost effective programme which will make the teachers to be the best they could in the school system and in the teaching profession.
\end{abstract}

Keywords: Mentoring, new teachers, administrative skills, mentor teachers, mentee, mentoring relationship

\section{Introduction}

Relationship is very important in human life. It is more important when human beings come together to form associations, societies and groups within the community. Whether the association or group formed is business or social oriented, relationship among the members is an important matter towards achieving the goal and purpose of the association.

The school as a social and academic organization exists on relationship and it cannot make impact within or outside without good relationship within and without. Relationship within 
the school can be of various kinds; staff and students, staff and staff, and students and students. Relationship at these different levels can either be formal or non-formal depending on the purpose of interaction. Relationship between the staff can be of equal status or between senior and junior colleagues. One of the expected relationships for professional development between senior and junior colleagues among teachers in our educational setting is mentoring.

\section{What is Mentoring?}

Mentoring comes from the root word 'mentor' which is a noun, mentoring itself as a verb describes the process. Longman Dictionary of Contemporary English (2008) defines mentoring as a "system where people with a lot of experience, knowledge, etc advise and help other people at work or young people preparing for work". Koki (1997) defines mentoring in education as "a complex and multi-dimensional process of guiding, teaching, influencing and supporting a beginning or new teacher. It is generally accepted that a mentor teacher leads, guides, and advises another teacher more junior in experience in a work situation characterized by mutual trust and belief". Furthermore, Wong and Prekumar (2007) see mentoring as "a learning process where helpful, personal and reciprocal relationships are built while focusing on achievement; emotional support is a key element".

From the above definitions of mentoring, one can deduce the following:

(i) It is a relationship - between mentor and mentee, and a reciprocal one.

(ii) It is intentional. Both determined and decided to enter into the relationship.

(iii) It is formal - at work or in a work situation.

(iv) It is a nurturing process which fosters the development of the mentee towards his full potential.

(v) It is collaborative and beneficial/rewarding to both parties.

(vi) It is based on or characterized by mutual trust and belief.

Mentoring therefore is a very important system in educational development among the teaching staff in an institution. It encourages the new/young teaching staff. It makes teaching activities very attractive to the new/young staff and stabilizes young and new staff in the teaching function. Mentors also benefit tremendously also as they see themselves contributing towards the growth and success of other people at work and being a role model to the new/young teacher. Mentors also evaluate themselves on their mentoring activities and strive for improvement on the task.

\section{Mentoring and Other Related Terms}

Considering other related terms to mentoring in education helps to note the magnitude of mentoring over and above all those related terms.

Modeling: "This is the process of serving as a model. A model is a tangible embodiment of an idea/or ideal (product). One of the functions of a mentor is to be a positive model". 
Coaching: "This is the assistance that one teacher provides to another in the development of teaching skills, strategies, or techniques generally within a formal three-part structure: peer conference, lesson observation, and post conference. In doing classroom observation in mentoring, the coaching structure is commonly used to structure the classroom observation by the mentor. Coaching by mentor may also become an essential activity if this type of support is needed by the beginning teacher". Mentoring encompasses modeling and coaching as the case may be. Neither modeling nor coaching is in itself mentoring. But the two of them are activities embedded in mentoring as mentoring is broader than any of the two.

\section{Qualities of a Mentor Teacher}

The functions of the mentor teacher vary depending on the needs of the new employee, the goals of the mentoring programme and the local and broader educational context or situation. It should be kept in mind that the mentor teacher is a helper, not a supervisor or evaluator, and a "very special person, a model of professionalism" (Hawai, Office of Personel Services, 1993).

Hawai's experience with mentoring has identified the following essential qualities of mentor teachers:

1) A range of interpersonal skills to fit a variety of professional encounters and situations.

2) Good working knowledge of a repertoire of teaching methods, alternative modalities of learning, and styles of teaching and learning that affect student achievement. He must be highly knowledgeable in methodologies of teaching and teaching outcomes in learners.

3) Ability to use coaching processes that foster increased self-direction and self-responsibility of the beginning teacher. He must be a motivator and encourager indeed. As a coach, he is with the mentee in practicalities of what he says or teaches and not theorizing.

4) Effective communication skills that facilitate the growth of the new employee and accommodate the employee's emotional, social and cognitive needs. He must be a good communicator.

5) Understanding the stages of teacher development within the context of how adults learn. He must be sensitive to the action and reaction of his mentee, interpreting what such means and adjust his style of mentoring to meet his mentee's learning aspiration. Furthermore, Universal Basic Education (UBE) programme stipulates the following as qualities of a mentor.

(i) Self-Awareness: Mentors should be aware of himself and should not want to relive himself through the mentees. He must be self-aware enough to keep personal idiosyncrasies and information separate from what is happening with or to the mentee.

(ii) Self-Development: The mentor should be keen at his own self-development too on the job. He could have had a mentor before. He should be interested in his subject association, attending meetings of mentors and interacting with mentors around, reading 
more, etc to ensure that he is developing himself on the job in order to help his mentee.

(iii) Attitude: The mentor's attitude to the programme mentoring, the mentee, and other mentors are very important. The attitude can either be positive or negative and each of these attitudes affects the programme.

(iv) Ambiguity: The mentor should be able to handle confusing situations and circumstantial changes that affect the work or the programme of mentoring as may even affect the mentee also.

(v) Styles: This has to do with the ways in which the mentor handles ambiguity, develop himself and behave in ways which lead others to trust, and respect him. And these depend on a variety of styles. The more flexible the mentor is the more skilled he will be at interacting with a range of mentees.

Furthermore, Malderez and Bodóczky(1999) while discussing what a mentor is quoted Fullerton and Malderez(1998) on the roles of mentors and gave the roles of mentors in a table as following:

Table 1. Roles of mentors.

\begin{tabular}{|c|c|c|}
\hline $\mathrm{S} / \mathrm{N}$ & Role & Functions \\
\hline 1. & Model & $\begin{array}{ll}- & \text { to inspire } \\
- & \text { to demonstrate }\end{array}$ \\
\hline 2. & Acculturator & $\begin{array}{ll} & \text { to show mentee the ropes } \\
- & \text { to help mentee get used to the particular professional culture }\end{array}$ \\
\hline 3. & Sponsor & 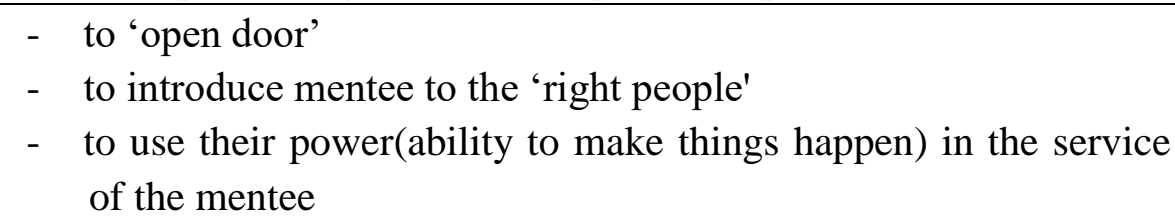 \\
\hline 4. & Support & $\begin{array}{l}\text { - } \text { to be there } \\
\text { - to provide safe opportunities for the mentee to let off } \\
\text { stream/release emotions } \\
\text { - to act as a sounding board - for cathartic reasons }\end{array}$ \\
\hline 5 . & Educator & $\begin{array}{l}\text { - } \text { to act as a sounding board - for articulation of ideas } \\
\text { - } \text { to consciously create appropriate opportunities for the mentee } \\
\text { - } \quad \text { to achieve professional learning objectives }\end{array}$ \\
\hline
\end{tabular}

Malderez and Bodóczky concluded therefore that: while any or any combination of the roles above would seem to us to justify the term 'mentor', most mentors will be involved to a greater or lesser degree in all five roles. This is particularly true of those mentors who are part of formal professional development schemes.

\section{Towards Starting a Mentoring Programme}

Once the necessity of mentoring has been established, it is therefore necessary to examine the 
process of starting a viable mentoring programme.

Four major processes have been identified for schools to deal with in starting a mentoring program. These tasks are (1) selecting and training individuals to serve as mentors (2) matching mentors with protégés (3) setting goals and expectations and (4) establishing the mentoring programme (Koki, 1997).

1. Selecting and training of mentors: This is the first task in starting a mentoring programme. This task should be a joint task between the schools and the old hands in the school. School authority can select, and staff - old hands that are interested in mentoring younger people can also volunteer themselves. There are no hard and fast rules about which traits or circumstances are most critical in given mentoring situation. The most important characteristics of effective mentor are a willingness to nurture another person. Someone that is recruited or volunteered to be a mentor should be people-oriented, open-minded, flexible, empathetic and collaborative. The mentor should also be trained in a mentoring training programme to be effective. Mentor training programme includes training in communication and active listening techniques, relationship skills, effective teaching, models of supervision and coaching, conflict resolution and problem solving (Koki, 1987).

2. Matching mentors and protégés: This is another important step in starting mentoring programme. Many considerations will come to focus here but what is utmost is that the two parties are desirous of working together. The mentor is ready to mentor and the protégé is desirous of being mentored. One of the issues to be considered in matching mentor/protégé is proximity. Proximity greatly facilitates the mentor/protégé relationship. In addition to personal and professional traits, other pertinent ways of establishing good matches between mentor and protégé are: a common ethnic, racial, cultural or class background, similarity of work assignments and others.

3. Setting goals and expectations: Any programme without goals will end up achieving nothing. For an all-important programme as mentoring there is the need to set up specific goals and expectations. Each mentor-protégé pair must have specific and appropriate goals. The school authority should help the mentor-protégé in developing appropriate goals and expectations of the mentoring programme. The authority should model the process by deciding on their own goals and having their protégés - the mentors - share expectations.

4. Establishing mentoring programmes: It is being recommended that once the goals are set, it becomes timely to establish the mentoring programme so that it will support the mentor-protégé pairs "throughout the development of their relationship". An initial step is to build a support structure that includes the making of physical arrangements and the handling of logistics. Another step is to create mechanisms for monitoring and communicating to ensure continual assessment of the relationship. A third step is to evaluate the staff developers' skills and abilities, and the mentoring programme.

The emotional and social aspects of the mentoring process must be respected in establishing a mentoring programme. Sensitivity is a necessary dimension of sharing professional expertise, personal knowledge and creativity. Therefore, staff developers working with mentors and 
mentors working with protégés must work toward competence in such areas as counseling, mediation, negotiation, intervention and clinical supervision (Koki, 1997).

\section{Phases in the Mentoring Relationship}

Mentoring relationship is in phases. Some of researchers and authorities have identified phases in mentoring relationships. Wong and Premkumar (2007) quoting Zachary (2000) identified four phases in mentoring relationships thus; (i) preparing (ii) negotiating (iii) enabling (iv) coming to closure.

All these phases are connected like chain as one leads to another. Step one leads to two, two-leads to three, and three to four.

Charney(2000) observes that each phase in the mentoring relationship involves active participation of both the mentor and the protégé. There is no one phase that excludes either one or the other hence mentoring is a relationship and relationship does not exist without any other person.

\section{Preparing for the mentoring relationship}

This initial phase can be compared to preparation for an important project. The mentor has to reflect on his motivation for engaging in a mentoring relationship and assess his readiness for the mentoring relationship. Motivation has great impact in sustaining a relationship. The mentor has to be assured of his readiness towards mentoring relationship. It is important also for the mentors to identify or discover the individuals they are mentoring. It is discovered that an important element in facilitating adult learning is helping learners become aware of their own idiosyncratic learning styles. Learning styles refers to the pattern of preferred responses an individual uses in a learning situation. Dialogue between the mentoring partners at the negotiation phase will assist the mentor in knowing when to step forward and when to hold back, and to respect different styles that may have a positive impact on the mentoring relationship.

\section{Negotiating the mentoring relationship}

This is the phase when the mentoring partners come to agreement on learning goals and define the content and process of relationship. It usually begins with a free-flowing conversation that takes place over one or more occasions and results in a shared understanding of the desired outcomes and delineation of responsibilities. At the end of this phase, the mentoring partners should ideally have collaboratively explored:

- Desired learning outcomes

- Criteria for measuring success

- Mutual responsibilities

- Accountability assurances

- Protocols for addressing problems

- An action plan for achieving the learning goal

One of the most important outcomes of the negotiating phase is boundary setting by both the 
mentor and the mentee. From the mentor's perspective, boundary has to do with the expectations of access and time. Both mentoring partners need to decide on when and where to meet, what the agenda will be for a meeting, and establishing a mechanism to indicate that a topic has been sufficiently explored.

\section{Enabling the mentoring relationship}

This has to do with making the mentoring relationship work or sustaining the mentoring relationship. A good mentor should be committed to three values. He should be disposed to opening himself to his mentee. For example, he should allow his mentee to observe him in action and convey to him the reasons behind his decisions and actions. Secondly, a mentor should be prepared to lead his mentor incrementally overtime. And thirdly, a mentor should be willing to express care and concern about the personal and professional welfare of his mentee.

Wong and Premkumar (2007) quoting Zachary (2000) identified some specific process skills that can facilitate the mentoring process which mentors must be familiar with in addition to their expertise and experience. These are:

1). Asking questions that will help mentees to reflect and articulate their own thinking, e.g.

* Could you tell me a bit more about what you mean by....?

* That's an interesting way of describing the problem. How do you apply that to individuals of a different gender?

2). Reformulating statements help mentors to clarify their own understanding and encourage mentees to reflect on what they articulate, for example;

* I think what I heard you saying were....

* My understanding is .....

3). Summarizing helps to remind the mentoring partners of what has transpired and allows both parties to check out assumptions in the process.

4). Listening for silence - Silence can indicate boredom, confusion, discomfort or embarrassment. On the other hand, some individuals just need to think quietly.

5). Providing feedback that is authentic and suggest future action, for example;

* I like the way....next time you might.....

* You made a really good start with....what I'd like to see is....

\section{Coming to closure in the mentoring relationship}

When mentors and mentees are involved in a formal mentoring relationship, there is usually an externally structured timeline for the mentoring relationship to come to an end. In informal mentoring relationships, it is helpful for the partners to agree at the beginning on the process for coming to closure. The process of coming to closure can be situated around a focused conversation about the specific learning that had taken place during and as a result of the mentoring relationship. Reference can be made to negotiating the mentoring relationship 
phase.

\section{Who are the New Teachers?}

For the purpose of this discussion, new teachers may be any of the following:

- Those not trained in the teaching profession,

- Those trained but entering into full time teaching for the first time,

- Those trained teachers but not experienced in teaching (1 - 4years),

- $\quad$ Already teaching but found teaching uninteresting.

- All the categories of teachers mentioned above need mentoring.

\section{Administrative skills on which the 'New' Teachers can be mentored}

1) School records keeping: Identifying the school records to be kept, understanding the need and importance of school records to be kept, recording into and or marking of the school records and keeping and proper maintenance of the school records being kept etc.

2) Classroom management (skills/control): Proper arrangement of the learners and their seats, keeping classroom neat and tidy, orderliness - the arrangement of wall pictures, charts and posters, making use of eye contact in classroom control, proper selection and involvement of class captain or monitor and instilling self-discipline in the learners etc,.

3) Teaching effectiveness and efficiency: Understanding different teaching methods and using the best method (eclectic) of teaching each topic, use of effective teaching apparatus, proper evaluation of learning outcomes, adequate preparation for teaching etc.

4) School community relations: Being friendly with all in the school, being cooperative with all the colleagues, developing skills of good relationship with all colleagues and school authority as well, working or striving for the peace, progress and stability of the school community.

5) School - community relations: Being friendly with all the people in the school community most especially parents of the students in the school, being approachable by all in the community, contributing to the peace, progress and stability of the community at large etc.

6) School plant management: Ensuring that the school environment is neat and tidy always by inculcating such into his students so they maintain neat and tidy classrooms and the school as a whole, ensuring that lawns are well kept, and ensuring proper maintenance of school facilities, equipment and even building. Reporting any damages in the school plant to the appropriate quarters or authorities for immediate repair etc. 


\section{Macrothink}

Journal of Public Administration and Governance ISSN 2161-7104 2017, Vol. 7, No. 3

7) Evaluation and assessment of students: Identifying different methods of evaluating and assessing students and applying the most appropriate ones at different situations, giving students outcomes of the assessment or evaluation and making use of the outcomes to make decisions and take actions.

\section{Benefits of Mentoring}

1. Providing on-the-job training opportunity for teachers

2. Ensuring teachers' retention on the job

3. Supporting teachers' maximum performance (output) in teaching

4. Encouraging teachers' aspiration for excellence in the profession

5. Developing teachers' competence in handling administrative matters

6. Developing teachers' interest in teaching

7 Improving teachers' relationship skills

8. Impacting and being impacted by others in the teaching profession

\section{Conclusion}

One of the best reforms in education is mentoring. Mentoring as a programme is very cost effective. As a programme of relationship, it helps to increase and improve quality and good relationship as such it is a programme of life. Every teacher, old and young should be positive towards mentoring, embrace it and be fully involved and active in it. Every teacher should have a point of entry into mentoring and possibly be in it as either a mentor or mentee. A school that is fully involved in mentoring will always reaps the benefits of the program and stand ahead of other schools without it. Mentoring is a programme to be fully adopted by our policy makers and be fully enshrined in our national policy on education.

\section{References}

Charney, C. Y. (2000). Your Instant Advisor: the A - Z Guide to Getting Ahead in the workplace. London: Kogan Page Limited.

Koki, S. (1997). "The Role of Teacher Mentoring in Educational Reform" in Pacific Resources for Education and Learning (pp 1-5).

Malderez, A., \& Bodóczky, C. (1999). Mentor Courses: A Resource Book for Trainer-Trainers. United Kingdom: Cambridge University Press.

Pearson Education Limited. (2007). Longman Dictionary of Contemporary English: The Living Dictionary. England: Longman.

Universal Basic Education Programme. (2003). Cluster Teacher Professional Support: A Training Manual for Teachers, Headteachers and Teacher Educators. Ibadan: Stirling-Horden Publishers Nig. (Ltd). 


\section{Macrothink}

Journal of Public Administration and Governance ISSN 2161-7104 2017, Vol. 7, No. 3

Wong, A. T., \& Premkumar, K. (2007). An Introduction to Mentoring Principles, Processes and Strategies for Facilitating Mentoring Relationships at a Distance. http://www.usask.ca/gmete/drupall/?q=resourcescontactangie.wong@usask.caorkalyani-prem kumar@usask.ca

\section{Copyright Disclaimer}

Copyright for this article is retained by the author(s), with first publication rights granted to the journal.

This is an open-access article distributed under the terms and conditions of the Creative Commons Attribution license (http://creativecommons.org/licenses/by/4.0/). 